\title{
The West and the Rest Divide: Human Rights, Culture and Social Work
}

\author{
Vishanthie Sewpaul ${ }^{1}$ (D)
}

Published online: 21 March 2016

(C) Springer International Publishing 2016

\begin{abstract}
Based on historical antecedents and continuing forms of imperialism, contemporary constructions of the world are exemplified by divisions, cultural conceit and skewed socio-economic development within and across nations. There is a tendency to present Western and Asian/ African "culture" and social work as monolithic and dichotomous entities, thus reinforcing essentializing discourses on culture and social work, which I contest by dealing with three major issues - culture, human rights and neoliberalism. The inextricable relationship between socio-economic development, democracy, culture and human rights, with intersecting "race", gender and national/regional belonging are predisposing determinants of poverty and human rights violations, which have important implications for social work education, research and practice.
\end{abstract}

Keywords Culture · Imperialism · Human rights ·

Neoliberalism · Ideological hegemony ·

Consciousness-raising

\section{Introduction}

The footprint of colonialism, and contemporary forms of imperialism affect conceptualizations of the West and the Rest, with each segment of the divide being attributed distinctive cultural and socio-political characteristics. The continuities and discontinuities between the past and the present, within a milieu of rapid globalization, influence social work

Vishanthie Sewpaul

Vishanthie.Sewpaul@zu.ac.ae

1 Zayed University, Dubai, United Arab Emirates education, research and practice in profound ways. One of the over-arching features of social work is its contextual focus. However, the understanding of, and responsiveness to, local situations must be embedded in an understanding of broader national, regional and global transitions, and in an increasingly interdependent world, social workers must possess the epistemological frameworks, and the knowledge, skills and values to, when possible, work across national and regional boundaries.

Social workers must harness the contradictory and competing strands of their histories, traditions and values, and the multiple identities within their contexts to develop vibrant, locally specific social work education, research and practices (Sewpaul 2007). But, the key question that must be asked: "Is this to be done at the expense of pitting Asian/African values against Western values, presupposing an absence of Asian/African values in the West and vice-versa?" There is a tendency to present Western and Asian/African "culture" and social work as monolithic and dichotomous entities, thus reinforcing essentializing discourses on culture and social work, which I contest by dealing with three major issues - culture, human rights and neoliberalism. This is preceded by acknowledging the power of history on contemporary interpretations of the West and the Rest.

\section{The Influence of History in the West and the Rest Divide}

Said (1977) speaks to the socio-political constructions of history indicating that, "History is made by men and women, just as it can also be unmade and rewritten, always with various silences and elisions, always with shapes imposed and disfigurements tolerated, so that "our" East, "our" Orient becomes "ours" to possess and direct" (p. xiv). This can be equally said about "our West" and "our Africa", oftentimes with debilitating inferences of inferiority attached to the Rest, and a rarefied 
cultural pride and superiority ascribed to the West, accompanied by an equal or exaggerated counter-claim by the Rest of its own superiority. Having warned about the making and remaking of history, in support of our own embellishments and biases, Said (1993) cogently discusses the power of the past, asserting that "there is no just way in which the past can be quarantined from the present. Past and present inform each other, each implies the other and, in the totally ideal sense [...] co-exists with the other" (p. 4).

Through colonialism and continued forms of imperialism, the West has an indelible imprint on the Rest, with an undermining of colonized peoples. Ferguson (2012) writes about six attributes other cultures lack that allowed the West to progress: (1) competition, which created the launch pad for nation states and capitalism; 2) science, which gave the West a major military advantage over the Rest; (3) property rights considered to be the bedrock of democracy and the rule of law protecting private ownership; (4) medicine that allowed for developments in health and life expectancies in the West and its colonies; (5) consumerism, referring to "a mode of material living in which the production and purchase of clothing and other consumer goods play a central economic role" (Ferguson 2012, p. 13); and (6) the work ethic, linked primarily to the moral framework of Protestant Christianity. While Ferguson exalts these attributes, the neoliberal and imperialistic values underscoring them have been widely critiqued in social work and related literatures.

Ferguson (2012) asserts, "it is not just Western superiority that led to the conquest and colonization of so much of the rest of the world; it was also the fortuitous weakness of the West's rivals" (p. 13). Glossing over the West's history of slavery, imperialism, racial segregation, and sexism, Ferguson (2012) unequivocally claims the moral, economic and political superiority of the West, maintaining that the scientific revolution was wholly Eurocentric, and he attributes to colonialism improvements in the life conditions of the colonized. Yet, colonized people have their own stories to tell. They remember the dismembering of their countries and families; the atrocities of enslavement; the land invasions; the destruction of indigenous values, beliefs and ways of living; the despair of living in the gaze of the colonizer (Fanon 1970); the sources of the West's wealth and might; and the lack of reparations.

Colonialism has changed the religious, cultural, economic and political landscapes of many countries across the Caribbean, Latin American, Asia-Pacific and African regions. Contemporary inter and intra-country ethnic violence, rooted in a colonial history (Annan 2006; Fanon 1970; Mutua 2006), is one of the major contributors to human rights violations, with poverty and inequality being precursors to and consequences of conflicts and human rights violations. The colonialists denied people their local languages and cultures and created arbitrary borders across national territories, forcing in some instances people of different ethnicities to live together
(Annan 2006; Mills 2011), and in other instances separated ethnic groups, entrenching division, fear, suspicion and prejudice (Mwansa and Kreitzer 2012). While none of the colonized countries escaped this, the Rwandan genocide, where more than 800,000 Tutsis were massacred in 1994, epitomized their consequences (Sewpaul 2014). The tragedy was that the Rwandan state, as with most post-colonial states, "mirrored its colonial legacy. The state [...] provided the institutional context and legitimacy for the discrimination and domination of one group by another" (Adejumobi 2006, p. 254). Reflecting on the numerous armed conflicts in Africa, Annan (2006) charged that Africa has been let down by African leaders, the international community and the United Nations.

Providing evidence of the devastating effects of structural adjustment programmes, the West's involvement in propping up illegitimate regimes, including the apartheid state in South Africa, and the murder of progressive, left-leaning leaders, Jeffery Sachs (2005, p. 198) asserts:

When it comes to charges of bad governance, the West should be a bit more circumspect. Little surpasses the Western world in the cruelty and depredations that it has long imposed on Africa [...] Far from lifting Africa economically, the colonial era left Africa bereft of educated citizens and leaders, basic infrastructure and public health facilities.

\section{Neoliberalism and Continuing Forms of Imperialism}

Colonized countries have undergone violent processes of decolonization, and share a strong history of human rights struggles. Yet, many post-independence states continue to be in chains with new forms of imperialism. There is a long history of coups by foreign governments and businesses. Between 1961 and 2004, there were 80 successful and 181 failed coups in Africa (Ngoma 2004). There is also a long history of US interventions in Latin America: Guatemala in 1954; Cuba in 1961; Dominican Republic in 1965; Chile in the 1970s and 1980s; counterinsurgency and death squads in Central America; invasions in Grenada and Panama; and the attempted coup in Venezuela in 2002. US Secretary of State, Henry Kissinger declared, with respect to Allende's socialist Chile, that it was within the rights of the US to "set the limits of diversity" in Latin America (Morris 1977, p. 241). During the Cold War, there was support for unconstitutional changes of government, mainly by the West. It was in the USsponsored dictatorships of Brazil, Chile, Argentina, and Uruguay, that neoliberalism was first imposed in Latin America. In the words of Annan (2006) "undemocratic and oppressive regimes were supported and sustained by the competing superpowers in the name of their broader goals" ( $p$. 
241) - the broader goals being primarily the disavowal of communism, the propagation of neoliberal ideology and securing domestic trade and profit.

Neoliberalism refers to a combination of socioeconomic and political discourse and policy choices based on the values of an unregulated market; trade liberalization; the rarefication of individual freedom and choice; and faith that market fundamentalism, not state intervention, would promote economic growth, progress and distributional justice, primarily through trickle-down effects (Sewpaul 2015a). While global economic integration is contributing to economic growth in some parts of the world, it is also accompanied by increasing poverty and inequality, conflicts and gross human rights violations. It is morally indefensible to relegate to the free market - that prioritizes profit above people - the healing of the sick, the education and housing of the poor and the care of the homeless, in a global environment where millions of people are food insecure and don't know where their next meal is coming from. The Nobel prize winner, economist, Krugman (2009) asserted that financial globalization, characterized by deregulation and liberalization of international trade and capital flows, "has definitely turned out to be even more dangerous than we realized" (p. 190). The global economic crises that began at the end of 2007 disproportionately affected people of colour, even in rich countries, with minority groups in the USA losing $43 \%$ of their net worth compared with $26 \%$ for Whites (DeBold et al. 2015). Before the recession, White families in the USA, on average, were four times wealthier than nonWhite families; by 2010, Whites were six times wealthier (Lowrey 2013).

Under circumstances of extreme poverty and inequality, it is easy for leaders to manipulate identities, as reflected in civil strife in many parts of the world, including Afghanistan, Yemen, Syria, Ukraine, Jordan, Burundi, the Democratic Republic of Congo, Somalia, Sudan, Rwanda, and the xenophobic outbreaks in South Africa. As social and economic conditions deteriorate, insecurity and instability, and human rights abuses increase (Cilliers 2006). Endemic diseases like malaria in some parts of Africa, and the high prevalence of HIV/AIDS and tuberculosis exacerbate poverty, opening Africa to the world of humanitarian aid, consultants and international corporations, where the "imperial game [is] being played out" (Mills, p. 326). Skewed development within and across countries, and growing inequality across the globe present the greatest threats to human security. Former head of the International Monetary Fund, Michel Camdessus, (cited in Shah 2011) concluded that, "the widening gaps between rich and poor within nations is morally outrageous, economically wasteful and potentially socially explosive". Pathetically though, within the neoliberal framework, the poor are considered incompetent, precluding an interrogation of structural determinants of poverty, and equating human worth with material accomplishment. Social and economic exclusions are fostered by the process of othering, based on criteria such as "race", 1 religion, ethnicity, nationality, sexuality and gender, and refugees and asylum seekers are deemed to be the undeserving other, which is accentuated in the existing climate of global terrorism and Islamophobia. Republican Presidential candidate, Donald Trump's incendiary and damning call, on 7 December 2015, for the banning of entry of Muslims, particularly Syrian refugees, into the USA is bound to reinforce anti-Western sentiments and Islamic backlashes, especially from extremist groups such as ISIS, Al Shabab and Boko Haram.

Neoliberal capitalism contributes to the commodification of every facet of peoples' lives, where anything including human beings can be bought and sold. Human trafficking, in its various facets as Mapp (2014) discusses, is a major problem facing mainly developing countries. The privatization of state assets, cutbacks in public expenditure on health, welfare and education, and liberalization of trade have devastating effects on people. Although by no means radical, Mills (2011) accedes to the limits of capitalism, "not least because of its 'boom and bust' nature and the costs this inflicted on the poor and vulnerable, the inevitable widening of wealth divides within society under this system and the political tensions that emanated from these" (p. 62).

Political tensions and deprivation contribute to a scramble for scarce resources and control of states based on despotism, nepotism and ethnic allegiances, entrenching conflicts and state failures. Many failed states have become "free trade zones for the underworld, where the black market in arms and in diamonds, and also trafficking in human beings, passports, gold and narcotics, connects local players to the global underworld economy" (Cilliers 2006, p. 245). Gross human rights violations are condoned in the interests of global capital where organized international crime and multi-national corporations play huge roles, reflecting a complicit relationship between leaders of the West and the Rest, thus paving the way for internal strife and revolution as seen in The Arab spring, with the toppling of dictatorships in Tunisia, Egypt and Libya (Sewpaul 2014). While acknowledging the dreadful effects of colonialism, Annan (2006) asserts that post-colonial countries must look beyond the colonial past for the causes of their current conflicts.

A continuing form of imperialism is the neoliberal appropriation of age-old cultural practices. Biopiracy, "the appropriation of knowledge and genetic resources of farming and indigenous communities" (ETC Group, undated) without compensation, is becoming increasingly common, resulting in the formation of global watchdog groups, and lawsuits

\footnotetext{
${ }^{1}$ I use "race" in inverted commas to indicate that it is not real, but a sociopolitical construct, exploited to create and maintain hierarchies of power, patterns of inclusion/exclusion, and subordination over some groups by others.
} 
particularly against the USA. Browne (2000) writes about the "Rush for Green Gold" in respect of RicTec in the US, which was granted a patent on the world-renowned basmati rice, against which the Indian government launched a successful legal challenge. Patents on products like basmati, turmeric and other indigenous plants used for medicinal purposes impact poor farmers who then have to pay fees to grow their crops, and they affect the export markets of developing countries. There are other forms of neoliberal takeover of cultural practices, with a cultural arrogance attached to them. When, for example, indigenous peoples of Latin America and Africa carry their babies on their backs, often as they engage in backbreaking farm or domestic labour, they are deemed to be backward, uncivilized and traditional. Yet, when this idea is stolen from them and we, as westerners, carry our children in expensive, designer label baby carriers in front, we are deemed to be smart, civilized and progressive, with stimulation of scientific studies into the effects of baby carrying (see e.g. Norholt 2012). Thus, the entrenchment of the language of othering, the dynamics of inferiority-superiority, and the rarefication and/or demonization of the Other, but they are not, and cannot be one of us.

\section{Liberal Democracy and the Market}

There are some arguments that liberal democracy, with its individualistically based values, is ill suited to Asia and Africa (Cobbah 1987; Merry 2006), and there is a fallacy to presume the benefit of liberal democracies for the West. Within liberal democracies, right wing conservatives appropriate much of the language of empowerment, often as justification for denial of human rights, with Neocosmos (2006) arguing that, "the liberal state $[\ldots]$ simply manages capitalist interests" (p. 12).

Neoliberalism was engineered and has become consolidated primarily on account of the lure of the language of liberal theory with its emphases on individualism, ownership, choice, flexibility, and competition that mask "the grim realities of [...] naked class power" (Harvey 2005, p. 119), in which the media plays a powerful role. The media not only manufactures consent, but desire as well (Leonard 1997) as the market seduces people into believing that their worth is decided by their ability to make correct purchasing choices (Bauman 1993). Bauman (in Bauman and Tester 2001) speaks of the "disguise of the individual's freedom of choice," which is so taken for granted that it is "seldom examined and questioned" (p. 87). Citing several power elites that serve as the main advocates of neoliberalism, Steger and Roy (2010) conclude, "These individuals saturate the public discourse with idealized images of a consumerist, free-market world [...]. Neoliberal decisionmakers function as expert designers of an attractive ideological container for their market-friendly political agenda" ( $p$.
11-12). These views are suggestive of Althusser's (1971) and Gramsci's (1977) thesis of ideological hegemony exercised by the state and civil society to control the consciousness of people, not through coercion but by gaining popular consent in the reproduction of prejudices and class relations. Neoliberalism penetrates daily consciousness so much so that it is normalized and naturalized, and it is considered necessary for social order despite the gross inequalities and poverty that it engenders (Harvey 2005), and in this, argues Haiven (2011), we are all complicit. We all engage in the reproduction of power hierarchies based on "race", class and gender.

While neoliberalism is widely critiqued, few are willing to critique the liberal democracy that underpins it. Alain Badiou (cited in Neocosmos 2006) asserts that, "The twentieth century has been, in fact, that of the power of the state [...] In truth everyone is prepared to criticize [...] the 'economic horrors' of neoliberalism [...] No one is prepared to critique liberal democracy. This is a taboo, a major consensual fetish. Liberal democracy is, in fact, the true subjective principle, everywhere in the world, of the support for liberal capitalism" (p. 11). There is a taken-for-granted assumption of a convergence between the market and democracy, with American liberalism being erroneously considered the source of democratic practice (Amin 2001; Harvey 2005; Sewpaul 2014). Gray (2009) declares that "democracy and the free market are competitors rather than partners" (p. 213), a view supported by Stiglitz (2006) who proclaims that neoliberal globalization is inconsistent with democratic principles. In reflecting on the influence of the new internationalism on social work, Mohan (2005) concludes, "It is dangerously naïve to romanticize the virtues of a free market in an unfree world [...] The point is that democracy per se is not a master panacea that will automatically transform an ossified system, a way of life deeply entrenched in anti-democratic traditions" (p. 243).

\section{Dichotomy Between Asian/African and Western Values}

In dichotomizing the West and the Rest, the West is characterized as liberal, expressive, egalitarian, individualistic, and pragmatic, and the Rest as authoritarian, patriarchal, hierarchal, collective and idealistic. Several authors view human rights, as reflected in the Universal Declaration of Human Rights (UDHR) (United Nations 1948), as a Western construct with limited applicability to non-Western contexts (Cobbah 1987; Merry 2006; Pollis and Schwab 2006; Mutua 2006). Healy et al. (2014) aver that this claim is erroneous, pointing to scholarship and practices that support the structural and collective dimensions of human rights. Notwithstanding the popular critique that universal human rights instruments are rooted in Western individualism, the African (Banjul) Charter 
on Human and People's Rights, adopted by the OAU in 1981 embraces all three generations of rights, reflected in the UDHR. It makes an effort to marry universal human rights, with culturally specific norms with emphases on the collective, the family and community, and on duties. First generation rights include civil and political rights such as free speech and conscience and freedom from torture and arbitrary detention. Second generation rights are social, economic and cultural and include the rights to reasonable levels of education, healthcare, and housing and minority language rights, as embodied the International Covenant on Economic, Social and Cultural Rights of 1996 and Articles 23-29 of the UDHR. These rights require government intervention; they are incremental because they have direct financial implications. Third generation rights focus on the natural world, such as the right to a clean and healthy environment, to inter-generational equity, and the right to species biodiversity.

There are merits to collective responsibility and communal caring as seen in extended family systems of caring for the elderly and children. However, the virtues of the collective have often become tainted and abused in the political arena (Sewpaul 2014). While Cobbah (1987) exalts the subordinate position of individuals in relation to the clan, Adejumobi (2006) warns about the dangers of group and ethnic identification, highlighting the case of Rwanda where, "Rights and citizenship have been largely defined and institutionalized as a group affair $[\ldots]$ reconstructed and legitimized by the colonial state. Citizenship [...] was not a 'universal' and common public good in Rwanda. It was exclusionary and bifurcated," (p. 255). The numbers of conflicts, charges of corruption, and human rights abuses on the basis of ethnicity speak to the gap between rhetoric and reality. There are idealized notions of communal caring and respect for traditions, yet we see the most inhumane violations, especially against civilians including women and children. The rhetoric - reality split is not unique to Africa and Asia; the West is also guilty. All forms of violent extremism, whether on the basis of religion, culture, sexuality, gender, "race" or nationality, anywhere in the world, must be condemned.

We also need to be mindful of the culturalization of the survival and struggle strategies of the poor, and of migrants, refugees and asylum seekers. Is culture used to make a virtue out of necessity? Is the presence of extended family structures and communal living patterns a reflection of cultural preference or a socio-economic necessity? Economics, not culture often dictate that adult children in both the Global North and the Global South, who have been living independently, return to the parental home following job losses, which has not been uncommon following the global economic recession of 2007/2008. While socio-economic factors influence patterns of savings and investments, and the rearing of children, these factors are often minimized in favour of cultural explanations.
We need to desist from idealizing Asian and African cultures based on collectivism, respect for family, and as embodying unifying and holistic principles as opposed to Western "culture", which is represented as fragmented, individualized and reductionist (Sewpaul 2014). The notion of an essentialist African, Asian or Western culture, which precludes the wide range of diversities within these contexts, must be disputed. There is no ontological stability to the West and the Rest, as these are constructed by people, partly as a result of identification by each with the other (Said 1977).

The attempt to disavow "cultural conceit" and "imperial tyranny" (Sen 2005, p. 107) is understandable considering the impacts of colonialism and imperialism. As a reaction to Western imperialism and superiority, Asian and African traditions are held as emancipatory alternatives to Western hegemony (Sewpaul 2007; 2014). For instance, Makgoba and Seepe (2004) assert that all that is Afrocentric is "emancipatory and liberatory" as opposed to that which is "authoritarian, patriarchal and Eurocentric" (p. 14), and they call for a replacement of the Eurocentric with the Afrocentric. In the Chinese context, Chung and Haynes (1993) emphasize the concepts of "love, humanity, perfect virtue and benevolence" implying their absence in the West. These authors go on to dichotomize Western culture as "low context culture" that is "left-minded" and Eastern culture as "relatively high context" and "right-minded" (p. 38). In a similar vein, Cobbah (1987) avers that respect, restraint, responsibility and reciprocity are distinguishing features of African society. The African, Cobbah (1987, p. 331) asserts, is socialized towards "wethinking resulting in a conception of the self that is unlike the Western conception."

There are inherent dangers in trying to substitute one form of domination with another, and as with the cultural conceit of the West, the arrogance of the Rest is unbecoming. While condemning the Western appropriation of human rights, Zeleza (2006) claims, "These dichotomies fly in the face of the fact that communality in Africa is often as exaggerated as individuality is in Europe [...] in both contexts, if they did indeed ever exist as discrete phenomena, individuals and community are mutually constituting and the practice of rights claiming, consuming or constraining them-entail a social context" (p. 47). Conservatism, authoritarianism and liberal and radical views co-exist in the North, South, East and West. Differences, within and across groups, countries and regions, must be celebrated insofar as such differences are not harmful to any group of persons.

Zeleza (2006) highlights the duplicity of Western human rights claims. While the UDHR was being signed in 1948, Jim Crow laws, enforcing racial segregation, were constitutional in the United States; indigenous peoples were poorly treated in the USA and Canada, and France and Britain were colonial masters. The USA, which sets itself as the moral authority on human rights, has a deplorable record of human rights abuses. 
Said (1977) points to the designedly aggressive attacks on the Arab and Muslim world for "their backwardness, lack of democracy, and abrogation of women's rights that we simply forget that such notions as modernity, enlightenment, and democracy are by no means simple and agreed upon concepts" (p. xiv). It is interesting to note that despite its claim to moral power, progress and democracy, the USA is the only country in the Global North that has not ratified the Convention on the Elimination of All Forms of Discrimination against Women (CEDAW). With Somalia having ratified the Convention on the Rights of the Child (CRC) in January 2015, and South Sudan in May 2015, the USA remains the only country that has not ratified the CRC (UN News 2015).

Sen $(1999,2005)$ questions the assumption that there has been a greater importance placed on tolerance and freedom in the West than in Asia. Liberty, freedom and reason are not part of an age-old Western heritage. There are examples of lack of tolerance for diversities in both the East and the West, and examples of Asia's greater tolerance. "There is little evidence" argues Sen (2005) "that Plato or St Augustine were more tolerant and less authoritarian than Confucius. While Aristotle certainly did write on the importance of freedom, women and slaves were excluded from the domain of this concern (an exclusion that, as it happens, Ashoka did not make around roughly the same time)" (p. 136). Another example used by Sen to refute such claims goes thus: "When Akbar was issuing his legal order that 'no man should be interfered with on account of religion' $[\ldots]$ and was busy arranging dialogues between Hindus, Muslims, Christians, Jains, Parsees, Jews and even atheists, Giordano Bruno was being burnt at the stake in Rome for heresy" (p. 136).

Sen (2005) exhorts that we distinguish between Western imperialism and Western civilization, arguing that resisting Western hegemony "has to be seen as a fight against submissive compliance, rather than as a plea for segregation and localism. The so-called 'post-colonial critique' can be significantly constructive when it is dialectically engaged - and thus strongly interactive - rather than defensively withdrawn and barriered" (p. 85). Simply because certain ideas, values, theories and technologies are linked to the West, they should not be rejected. Sen (2005) cites specific reasons why dichotomizing the East and the West is based on flawed premises. Given the historical, cultural and intellectual interconnections across the globe it is often hard to differentiate what is Western and what is Eastern. What constitutes "Western science" is difficult to delineate. Europe and America are not its sole custodian given that development in mathematics and science in the West drew chiefly from earlier developments in Arabia, China and India, and irrespective of where discoveries are made, knowledge rapidly becomes shared globally.

The dimension of cultural relativism and universal human rights warrants specific attention. Superstition, and patriarchal beliefs and structures are often the sources of human rights violations. While respect for diversity is a fundamental value of social work, and the profession grants eminence to unity in diversity, we need to ask, "how far do we stretch the boundaries of moral relativism?" Social workers must challenge the violation of basic rights to bodily integrity, to security, and to life that occur on the pretext of religion and culture. Female genital mutilation, honour killing, homophobia and its consequences, the killing of albinos and people deemed to be witches, and the murder of people to acquire body parts for traditional medicines all violate human rights in most brutal ways. They cannot be condoned within value systems that hold human dignity to be sacrosanct, and where respect, restraint, responsibility and the "we-thinking" (Cobbah 1987) are exalted. Indeed, genuine adherence to these cultural prescripts, can serve as constraints to human rights abuses (Sewpaul 2014). The problem with a commitment to "doing no harm" in the abstract, is that all too often, with the normalizing functions of socialization, and dominant socio-cultural discourses, harm does become normalized, with androcentric thinking and practices permeating many societies (Sewpaul 2013).

\section{Implications for Social Work}

The issues discussed in this article in respect of the historical antecedents to the West and the Rest divide, contemporary forms of neoliberal imperialism, the dichotomies in the values of the West and the Rest, and concerns around cultural relativism and universal human rights, have important implications for social work education, research and practice. Social work must shift from the predominant pathology-based casework, and system-stabilizing modes of operation. Empowering, strengths-based and emancipatory approaches to working with individuals, families, groups and communities can and does help in transcending the micro-macro divide (Sewpaul and Larsen 2014). In many respects, social workers are frontline human rights workers as they work with the most disadvantaged, marginalized and vulnerable of populations (Dominelli 2012; Healy 2008; McPherson 2014; Sewpaul 2014; 2015b). Behring (2013) writes about "turning the workspace of every social worker into a battlefront in defence of rights" (p. 92). However, as Healy (2008) argued social work must become more conscious of its activities as human rights practices, and build on daily practice to influence policy changes. We must reclaim social work as a "human rights profession" (Wronka and Staub Bernasconi 2012, p. 70). This is not new. In 1936, Bertha Reynolds, warned: "if they [social workers] do not stand courageously for all human rights, they will lose their own, including the right to practice their profession as a high and honorable calling" (p. 12). Understanding social work's radical roots is salient, as "we may find hope for our future by reclaiming our past: our 
profession's history is one of campaigning for the expansion of social, economic, and civil rights "(McPherson 2014, p.11).

Social workers can strive towards integrated social, economic, cultural and environmental development by supporting the goals of the Global Agenda (IASSW/IFSW/ ICSW 2012) that is committed to the International Labour Organisation's (ILO) Decent Work Agenda and the United Nations Social Protection Floor Initiative. The World Bank Group and the ILO joined forces in June 2015 to support the launch of universal social security, which is a key mechanism to ensure the fulfillment of socio-economic rights, arguing that, "Social protection systems that are well-designed and implemented can powerfully shape countries, enhance human capital and productivity, eradicate poverty, reduce inequalities and contribute to building social peace. They are an essential part of National Development Strategies to achieve inclusive growth and sustainable development with equitable social outcomes". This calls for redistributive and regulatory roles of states that social workers must support, rather than laissezfaire capitalist states that transfer responsibilities of health, education, and well-being to private providers, and to individuals, families and local communities, often in the disguise of choice, empowerment, self-reliance, and community care. To add to their woes, such transfers are often onto poor women, more particularly onto women of colour across the world.

Social workers can adopt non-violent non-cooperative strategies (Gandhi 2005) when people's well-being, security, bodily integrity and lives are threatened, and they must be willing to make public pronouncements to challenge structural injustices (Sewpaul 2015b). Several authors describe the activities of social workers that, as individuals or as part of organized groups, do challenge unjust policies and practices that maintain people in poverty and unequal positions (Briskman 2014; Dominelli 2012; Healy 2008; Ioakimidis et al. 2014; McPherson 2014; Sewpaul 2014). In the face of gross violations of rights, corruption, conflicts and the harmful effects of neoliberalism, the efforts of social work, on its own, would produce small gains. Social workers must agitate for political commitment and human will towards radical structural changes to promote peace, social democracy, development, justice and human rights (Sewpaul 2015b).

As social workers, we are products of our socio-political, economic and cultural worlds. The ideologies that we hold are reflected in, and reinforced by, dominant social systems such as the family, education, culture, economics, politics and the media (Sewpaul 2013). It is, therefore, critical that we become aware of cultural, political and capitalist ideological hegemony and appreciate how we can shift from being the "subjected being" to a free subject that is the "author of and responsible for its actions" (Althusser 1971, p. 182). With the development of critical consciousness (Freire 1973) there is a greater chance that social workers would use their voice and skills to contribute to socio-economic, political and cultural change and development. The Self must become the site of politicization (Sewpaul 2015b), and this politicization must begin in the classroom (Sewpaul 2013). Emancipatory social work is directed at heightening awareness of external sources of oppression and/or privilege that hold the possibility of increasing self-esteem, courage and conviction to confront structural sources of poverty, inequality, marginalization, oppression and exclusion (Sewpaul and Larsen 2014). This works as much for professionals, as they do for the people that social workers engage with.

One of the complex issues across the globe is the compromising of civil and socio-economic rights on account of specific cultural beliefs and practices (Adejumobi 2006; Sen 2005; Sewpaul 2014; Zeleza 2006). Social workers play important roles as cultural mediators, facilitating inter-cultural dialogue, debate and constructive confrontation when necessary. Social workers can adopt Freirian-GramscianAlthusserain strategies of consciousness-raising through praxis to enable people to challenge taken-for-granted assumptions that become inscribed through political, capitalist and cultural hegemony (Althusser 1971; Freire 1973; Gramsci 1977; Sewpaul 2013; 2014). Donnelly (2006: 103) argued that cultural relativism sometimes serves as a cloak for despotism, homophobia and patriarchy, which cannot justify derogation from universal human rights. The Global Standards for Social Work Education and Training specifically calls for social work students to be schooled in a basic human rights approach (Sewpaul and Jones 2005, p. 223), with the following accompanying footnote:

Such an approach might facilitate constructive confrontation and change where certain cultural beliefs, values and traditions violate people's basic human rights. As culture is socially constructed and dynamic, it is subject to deconstruction and change. Such constructive confrontation, deconstruction and change may be facilitated through a tuning into, and an understanding of particular values, beliefs and traditions and via critical and reflective dialogue with members of that cultural group vis-àvis broader human rights issues (Sewpaul and Jones 2005, p. 228).

Said (1977) advices that there is a "profound difference between the will to understand for the purpose of coexistence and humanistic enlargement of horizons, and the will to dominate" (p. xiv). Social work must be directed to the former. While doing no harm and respect for human dignity are held as inviolable, universal principles in social work, they are not without contestation. The interpretations of these, mediated by culture and context, often extend the boundaries of moral relativism to the point of violating human rights. While policy and legislation can provide safeguards, they are often trumped 
by cultural beliefs and practices. There is no foolproof moral guide against such violations except for dialogue; tuning into the life worlds of people; responsiveness; reasoned debate; recognizing the power of care, interdependence, reciprocity and validation; the willingness to resolve dissent in constructive ways; and when necessary non-violent non-cooperation. However, as I earlier (Sewpaul 2015a, b) concluded, there is a greater likelihood that by making the being for the Other principle the normative in social work, the profession would be able to contribute to a truly ethical politics and live up to the ideal of social work as politics with soul. Being for the Other exemplifies the ethical as sensitivity and commitment of one person to another.

For Levinas (1985) to be responsible means to make oneself available for the service of the Other in such a way that one's own life is intrinsically linked with that of the Other's. The appeal for such an approach lies in Bauman's (1993) assertion that the moral self accords the unique Other that priority assigned to the self. The justification for the self, for Levinas (cited in Bauman 1993), begins with the Other; our responses to the call of the Other define ourselves. Social workers have the requisite skills in empathy, active listening, facilitation, mediation and interpersonal relationships to engage people in such ways that the harmful aspects of culture are challenged, while retaining those that are positive and that allow for inter-generational cultural continuity and human flourishing, across the West and the Rest.

\section{Conclusion}

Based on historical antecedents and continuing forms of imperialism, contemporary constructions of the world are exemplified by divisions, cultural conceit and skewed socioeconomic development within and across nations. There is an inextricable relationship between socio-economic development, democracy, culture and human rights, with intersecting "race", gender and national/regional belonging being predisposing determinants of poverty and human rights violations.

Rather than dichotomize our worlds, and a defensive perpetuation of cultural aggrandizement across both the West and the Rest, as social workers we need to transcend our obscurantist positions, and coalesce around a common agenda defending the people whom we work with, the world we live in, and our profession from the assaults of unrestrained consumerism and capitalism (Sewpaul 2007). Social workers can represent voice by challenging the naturalized power of capitalism, its entrenchment of "race", gender and class hierarchies, and its devastating effects in the West, and more particularly the Rest. In doing so we must recognize the Power of One, the Power of Many and the Power of Now, whichwhen realized - grants one moral authority and integrity.
As individuals, each one of us can work within the spheres of our influence whether at micro, mezzo and/or macro levels, to make a difference, but as members of a collective we can make a world of difference. Finally, there is no greater lesson than living in the present, and dedicating ourselves $100 \%$ to tasks at hand, reflecting the importance of process and not just product, in working towards a utopian ideal of a better life for all. As no outcome can be guaranteed there should be no preoccupation with the outcomes of action. Such a detached disposition will ensure equanimity of response to any outcome. But constructive and dedicated attention to requisite action (e.g. studying for an examination without expending energy worrying about the results) is more likely to bring rewards. This is most succinctly stated in the Bhagavad Gita, where Lord Krishna says, "Thy human right is for activity only, never for the resultant fruit of actions ... neither allow thyself attachment to inactivity" (in Yogananda 1999, p. 281). In relation to the other connotation to the Power of Now, as Nelson Mandela, our world icon, said: "We must use time creatively, and forever realize that the time is always ripe to do right" (undated). There is no virtue in procrastination, especially in the face of a world going awry that requires our urgent attention.

The moral authority and integrity of social workers must be combined with an ability to build alliances across similarities and differences from personal to political levels; to mobilize others into a shared vision; and to support global social movements that work towards greater social justice, solidarity and respect for human dignity. Social work does have a contribution to make in promoting social justice and human rights at micro and macro levels, more especially at the intersection of these. Lifting micro levels of analyses and interventions to broader public issues brings social work into the realm of the political (Sewpaul 2015b). Social work, more than any other profession, holds the potential to function in that "intermediary site where 'life politics' meets Politics with a capital P: where private problems are translated as public issues and public solutions are sought, negotiated and agreed for private troubles" (Bauman, 2007, p. 24).

\section{References}

Adejumobi, S. (2006). Citizenship, rights, and the problem of conflicts and civil wars in Africa. In C. Heyns \& K. Stefiszyn (Eds.), Human Rights, peace and justice in Africa: A reader (pp. 250-271). Pretoria: Pretoria University Law Press.

Althusser, L. (1971). Ideology and ideological state apparatuses. London: New Left Books.

Amin, S. (2001). Imperialism and globalization. Monthly Review, 53, 2. http://www.monthyreview.org/0601 amin.htm. Accessed 6 December 2015. 
Annan, K. (2006). The causes of conflict and the promotion of durable peace and sustainable development in Africa. In C. Heyns \& $\mathrm{K}$. Stefiszyn (Eds.), Human Rights, peace and justice in Africa: A reader (pp. 239-243). Pretoria: Pretoria University Law Press.

Bauman, Z. (1993). Postmodern Ethics. Oxford: Blackwell Publishing Ltd.

Bauman, Z. (2007). Critique - privatized and disarmed. In A. Elliot (Ed.), The contemporary Bauman (pp. 19-26). London: Routledge.

Bauman, Z., \& Tester, K. (2001). Conversations with Zygmunt Bauman. Oxford: Blackwell Publishers.

Behring, E. R. (2013). The ethical-political project of social work in Brazil. Critical and Radical Social Work, 1, 87-94. doi:10.1332/ 204986013 X665983.

Briskman, L. (2014). Reflections on an activist social worker: Challenging human rights violations. In C. Noble, H. Strauss, \& B. Littlechild (Eds.), Global Social work: Crossing Borders, Blurring Boundaries (pp. 301-310). New South Wales: Sydney University Press.

Browne, A. (2000). India fights US basmati rice patent, The Guardian. http://www.theguardian.com/world/2000/jun/25/anthonybrowne. theobserver. Accessed 6 December 2015.

Chung, D. K., \& Haynes, A. W. (1993). Confucian welfare philosophy and social change technology: an integrated approach for international social development. International Social Welfare, 36, 37-46.

Cilliers, J. (2006). Human security in Africa: A conceptual framework for review. In C. Heyns \& K. Stefiszyn (Eds.), Human Rights, peace and justice in Africa: A reader (pp. 243-248). Pretoria: Pretoria University Law Press.

Cobbah, J. A. M. (1987). African values and the human rights debate: an African perspective. Human Rights Quarterly, 9(3), 309-331.

DeBold, T., Freidman, D., Molla, R, \& Zumbrun, J. (2015). Tracking inequality in America. http://graphics.wsj.com/inequality-inamerica/ Accessed 8 December 2015.

Dominelli, L. (2012). Green social Work: From Environmental Crises to Environmental Justice. Cambridge: Polity Press.

Donnelly, J. (2006). Cultural relativism and universal human rights. In C. Heyns \& K. Stefiszyn (Eds.), Human Rights, peace and justice in Africa: A reader (pp. 111-121). Pretoria: Pretoria University Law Press.

Fanon, F. (1970). The Wretched of the Earth. Harmondsworth: Penguin.

Ferguson, N. (2012). Civilisation: The West and the Rest. New York: Penguin Press.

Freire, P. (1973). Education for critical consciousness. New York: Seabury.

Gandhi, M. (2005). In K. Kripalani (Ed.), All men are brothers: Autobiographical reflections. New York: Continuum.

Gramsci, A. (1977). Selections from political writings 1910-1920. London: Lawrence \& Wishart.

Gray (2009). False dawn: the delusions of global capitalism. London: Granta Publications.

Haiven, M., (2011). From NYC: "Occupy Wall Street Has No Agenda" is an Alibi for Apathy, Halifax Media Co-op. http://www.mediacoop. $\mathrm{ca} / \mathrm{blog} / \mathrm{max}$-haiven/8378.(accessed 1.11.12.).

Harvey, D. (2005). The new imperialism. Oxford: Oxford University Press.

Healy, L. (2008). Exploring the history of social work as a human rights profession. International Social Work, 51(6), 735-748.

Healy, L., Thomas, R. L., Berthold, M. S., \& Libal, K. R. (2014). Fulfilling the rich potential of human rights in social work education: An overview. In K. R. Libal, S. M. Berthold, R. L. Thomas, \& L. M. Healy (Eds.), Advancing human rights in social work education (pp. 13-18). Alexandria: Council on Social Work Education.

IASSW/IFSW/ICSW (2012). Global Agenda. http://www.iassw-aiets. org/images/Documents/GA_E 8Mar.pdf. Accessed 27 June 2012.
Ioakimidis, V., Cruz Santos, C., \& Herrero, I. M. (2014). Reconceptualizing social work in times of crisis: an examination of the cases of Greece, Spain and Portugal. International Social Work, 57(4), 285-300.

Krugman, P. (2009). The return of depression economics and the crisis of 2008. New York: WW Norton.

Leonard, P. (1997). Postmodern Welfare: Reconstructing an Emancipatory Project. London: Sage Publications.

Levinas, E. (1985). Ethics and Infinity. Translated by R. A. Cohen. Pittsburgh: Duquesne University Press.

Lowrey, A. (2013). Wealth gap has widened since recession, Business Day. http://www.nytimes.com/2013/04/29/business/racial-wealthgap-widened-during-recession.html?_r $=0$. Accessed 6 December 2015.

Makgoba, M., \& Seepe, S. (2004). Knowledge and identity: An African vision of higher education transformation. In S. Seepe (Ed.), Towards and African Identity in Higher Education. Pretoria: Vista University.

Mapp, S. (2014). Human rights as a framework for teaching international social work. In K. R. Libal, S. M. Berthold, R. L. Thomas, \& L. M. Healy (Eds.), Advancing human rights in social work education (pp. 103-119). Alexandria: Council on Social Work Education.

McPherson, J. (2014). Human rights practice in social work: A US social worker looks to Brazil for leadership, European Journal of Social Work. DOI: 10.1080/13691457.2014.947245

Merry, S. E. (2006). Transnational human rights and local activism: mapping the middle. American Anthropologist, 108(1), 38-51.

Mills, G. (2011). Why Africa is poor and what Africans can do about it. Johannesburg: Penguin.

Mohan, B. (2005). New internationalism: social work's dilemmas, dreams and delusion. International Social Work, 48(3), 241250.

Morris, R. (1977). Uncertain greatness: Henry Kissenger and American foreign policy. New York: Harper and Row.

Mutua, M. (2006). The Banjul charter and the African cultural fingerprint: An evaluation of the language of duties. In C. Heyns \& K. Stefiszyn (Eds.), Human Rights, peace and justice in Africa: A reader (pp. 53-59). Pretoria: Pretoria University Law Press.

Mwansa, L. J., \& Kreitzer, L. (2012). Social work in Africa. In K. Lyons, T. Hokenstad, M. Pawar, N. Huegler, \& N. Hall (Eds.), The Sage handbook of international social work (pp. 393-406). London: Sage Publications.

Neocosmos, M. (2006). Development, social citizenship and human rights: Rethinking the political core of an emancipatory project in Africa. Unpublished paper presented at the Centre for Civil Society, University of KwZulu Natal. June 2006.

UN News (2015). www.un.org/apps/news/story/asp?NewsID=50759\#. VpJcQKXenM. Accessed 10 January 2016

Ngoma, N. (2004). Coups and coup attempts in Africa: is there a missing link? Africa Security Review, 13(3), 85-94.

Norholt, H. (2012). Does baby carrying promote attachment?. http://blog. ergobaby.com/2012/01/does-infant-carrying-promote-attachment/. Accessed 5 December 2015.

Pollis, A., \& Schwab, P. (2006). Human rights: A Western construct with limited applicability. In C. Heyns \& K. Stefiszyn (Eds.), Human Rights, peace and justice in Africa: A reader (pp. 88-96). Pretoria: Pretoria University Law Press.

Sachs, J. (2005). The End of Poverty: How We Can Make it Happen in our Lifetime. London: Penguin.

Said, E. W. (1977). Orientalism. London: Penguin.

Said, E. W. (1993). Culture and Imperialism. New York: Vintage Books.

Sen, A. (1999). Development as Freedom. Oxford: Oxford University Press. 
Sen, A. (2005). The argumentative Indian: Writings on Indian culture, history and identity. London: Penguin.

Sewpaul, V. (2007). Challenging East-West value dichotomies and essentialising discourse on culture and social work. International Journal of Social Welfare, 16, 398-407.

Sewpaul. (2013). Inscribed in our blood: confronting and challenging the ideology of sexism and racism. Affilia, The Journal of Women and Social Work, 28(2), 116-125.

Sewpaul, V. (2014). Social work and human rights: An African perspective. In S. Hessle (Ed.), Human Rights and Social Equality: Challenge. Surrey: Ashgate.

Sewpaul, V. (2015a). Neoliberalism. International Encyclopedia of the Social and Behavioral Sciences, $2^{\text {nd }}$ edition, 16: 462-468

Sewpaul, V. (2015b). Politics with soul: Social work and the legacy of Nelson Mandela. International Social Work. doi:10.1177/ 0020872815594226.

Sewpaul, V., \& Jones, D. (2005). Global standards for the education and training of the social work profession. International Journal of Social Welfare, 14(3), 218-230.

Sewpaul, V., \& Larsen, A. K. (2014). Community development: Towards an integrated emancipatory framework'. In A. K. Larsen, V.
Sewpaul, \& G. Oline (Eds.), Participation in Community Work: International Perspectives (pp. 230-246). London: Routledge.

Shah, A. (2011). Poverty around the world. http://www.globalissues. org/article/4/poverty-around-the-world. Accessed 6 December 2015.

Steger, M. B., \& Roy, R. K. (2010). Neoliberalism: A Very Short Introduction. New York: Oxford University Press.

Stiglitz, J. (2006). Making Globalization Work. London: Penguin.

United Nations (1948). United Nations Declaration of Human Rights. http://www.un.org/en/universal-declaration-human-rights/index. html. Accessed 7 December 2015

Wronka, J., \& Staub Bernasconi, S. (2012). Human Rights. In K. Lyons, T. Hokenstad, M. Pawar, N. Huegler, \& N. Hall (Eds.), The Sage handbook of international social work (pp. 70-84). London: Sage Publications.

Yogananda, P. (1999). God talks with Arjuna: The Bhagavad Gita. California: The Self-Realization Fellowship.

Zeleza, P. T. (2006). The Struggle for Human Rights in Africa. In C. Heyns \& K. Stefiszyn (Eds.), Human Rights, Peace and Justice in Africa: A Reader (pp. 42-48). Pretoria: Pretoria University Law Press. 